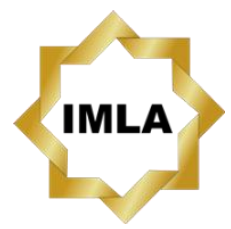

Available online:

http://journal.imla.or.id/index.php/arabi

Arabi : Journal of Arabic Studies, 5 (1), 2020, 63-78

DOI: http://dx.doi.org/10.24865/ajas.v5i1.190

\title{
PADANAN KOSAKATA ARAB DALAM AL-QUR'AN TERJEMAH VERSI INDONESIA DAN MALAYSIA
}

\author{
Rika Astari', Yusroh ${ }^{1}$, Abdul Malik ${ }^{2}$, Ahmad Arifin bin Sapar ${ }^{3}$, \\ Nurina Dyah Putrisari ${ }^{4}$ \\ 'Universitas Ahmad Dahlan, Yogyakarta, Indonesia \\ ${ }^{2}$ Universitas Sebelas Maret Surakarta, Indonesia \\ ${ }^{3}$ University of Malaya, Malaysia \\ ${ }^{4}$ Universitas Padjadjaran, Bandung, Indonesia \\ E-mail : rika.astari@bsa.uad.ac.id
}

\begin{abstract}
The purpose of this study is to describe the differences in the concept of meaning between the translation of the Qur'an in the Indonesian and Malaysian versions and explain the factors that influence the differences in the concept of meaning. This is a qualitative study that employs library material analysis with enrichment from the interview. Several material objects used, such as the Al-Wafi dictionary and Diwan dictionary, the quranic verses about women in the Malaysia Team of Islamic Progress (JAKIM), and Ministry of Religion RI in January 2017. The difference in its meaning was analyzed by lexical decomposition. It was concluded that the concept meaning of a word in Malaysian tends to be used in various contexts and has polysemy. The factors that influence of distinguishing in meaning concept are social, cultural, political, government policies. The translation of the Quran in the Malay language version tends to use the majazi expression and is more textual. The Indonesia translation of the Qur'an more contextual due to the influence of Islamic thought in Indonesia, which more moderate, tolerant, and accommodate local wisdom.
\end{abstract}

Keywords: meaning concepts, speaker perceptions, Malay equivalent translations

\begin{abstract}
Abstrak
Penelitian ini bertujuan mendeskripsikan perbedaan konsep makna antara kosakata terjemah al-Qur'an versi bahasa Indonesia dan Malaysia serta menjelaskan faktor yang memengaruhi perbedaan konsep makna. Penelitian ini menggunakan pendekatan deskriptif. Objek material penelitian ini adalah: kamus al-Wafi (2015), kamus Diwan; terjemah ayatayat tentang wanita pada JAKIM dan Kementrian Agama. RI versi online pada Januari 2017. Analisis perbedaan makna menggunakan metode dekomposisi leksikal. Disimpulkan bahwa konsep makna suatu kata dalam bahasa Malaysia cenderung dapat digunakan di berbagai konteks dan memiliki banyak makna (polisemi) jika dibandingkan dengan kata dalam bahasa Indonesia. Faktor yang memengaruhi perbedaan konsep makna yaitu faktor sosial, budaya, politik, serta kebijakan pemerintah. Al-Qur'an terjemah versi bahasa Malaysia cenderung menggunakan ungkapan majazi dan bersifat lebih tekstual, sedangkan Al-Qur'an terjemah Indonesia serasa lebih kontekstual karena pengaruh pemikiran keislaman di Indonesia yang lebih moderat, toleran, dan mengakomodir kearifan lokal.
\end{abstract}

Kata Kunci: konsep makna, persepsi penutur, padanan terjemah Malaysia 


\section{Arabi : Journal of Arabic Studies}

\section{Pendahuluan}

Bahasa merupakan media yang digunakan oleh manusia untuk berkomunikasi dan produksi arti, sehingga bahasa sangat erat kaitannya dengan kajian makna dan tata cara penerjemahan. Bahasa Arab sebagai bahasa pengantar di dalam al-Qur'an, dapat dikaji secara internal maupun eksternal. Kajian internal dapat berupa struktur fonologi, morfologi, sintaksis dan juga penerjemahan (Mahliatussikah, 2016). Makna ayat-ayat al-Qur'an hanya dapat dipahami oleh penutur yang memiliki kemampuan bahasa Arab yang baik (Bustam \& Astari, 2018). Penerjemahan kosakata Arab ke dalam berbagai bahasa, dapat dipengaruhi oleh latar belakang budaya masing-masing negara, sehingga hal ini memengaruhi pembaca dalam memahami ayatayat al-Qur'an. Penerjemah akan mendapatkan hasil yang baik jika penerjemah menguasai gramatika bahasa sumber, seperti pemahaman konsep kala (Nur, 2016).

Umat muslim di negara-negara selain Arab, banyak mengkaji dan menerjemahkan kitabkitab berbahasa Arab guna memperdalam ilmu-ilmu agama Islam. Pada penerjemahan teks, seringkali ditemui beberapa permasalahan, antara lain, kesalahan pada diksi, tata bahasa, tanda baca dan pemilihan kata yang memengaruhi kualitas teks target yang diterjemahkan (Sundari \& Febriyanti, 2017). Teks bahasa sasaran cenderung menggunakan kosa kata yang tidak sepadan dibandingkan dengan teks sumber, hal ini menghasilkan teks terjemah yang berbeda dari teks versi asli (Kenny, 1998). Pada al-Qur'an terdapat banyak fitur gaya bahasa dan retoris, sehingga penerjemahan al-Qur'an ke dalam bahasa lain mengalami kendala linguistik, seperti, masalah leksikal, sintaksis, metaphor, metonimi, elipsis, polisemi. Masalah utama yang dihadapi oleh penerjemah al-Qur'an terkait leksikal adalah kesulitan dalam memberikan padanan leksikal dari bahasa Arab.

Masuknya Islam serta penyebarannya telah memengaruhi bahasa di Indonesia dan Malaysia, bahkan memengaruhi berbagai aspek kehidupan, yakni agama, politik, sosial, keilmuwan serta budaya, meskipun kedua bahasa tersebut termasuk dalam rumpun bahasa Austronesia, kedua negara tersebut tetap memiliki perbedaan dalam menerjemahkan kosakata Arab ke dalam bahasanya masing-masing. Di Indonesia, pada terjemah dan tafsir al-Qur'an berbahasa Sunda, terjadi pertemuan antara prinsip dan nilai budaya Sunda dengan ajaran al-Qur'an. Semua diadaptasikan dalam kerangka ajaran al-Qur'an dalam bingkai budaya masyarakatnya (Rohmana, 2014).

Adanya keragaman bahasa baik di Malaysia maupun Indonesia, maka, kedua negara ini menerbitkan al-Qur'an terjemah versi bahasa resmi negara yakni versi bahasa Indonesia oleh Kementerian Agama (Kemenag.) RI dan versi bahasa Malaysia oleh Jabatan Kemajuan Islam Malaysia (Jakim). Penulis menemukan beberapa perbedaan pemberian makna pada penerjemahan kosakata Arab ke dalam bahasa Indonesia dan bahasa Malaysia, sehingga muncul pula persepsi

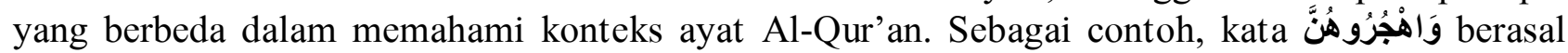
dari kata هَجَرَ - هَهْجُرُ - هَجْرً dalam kamus Diwan (Arab-Malaysia) memiliki makna: 'menjauhi, meracau, merekik, meninggalkan', sedangkan dalam kamus al-Wafi (Arab-Indonesia) memiliki makna: 'meninggalkan sesuatu, meninggalkan seseorang'. Kata وَاهُجُرُوهُنَّنَ dalam QS. 4: 34, terjemah versi bahasa Malaysia, kata ini diterjemahkan dengan 'pulaukanlah mereka' dan bahasa Indonesia diterjemahkan dengan: 'tinggalkanlah mereka'.

Perbedaan penerjemahan ini dilatarbelakangi oleh faktor budaya, pengetahuan tentang bahasa sumber dan bahasa sasaran penerjemah/penutur bahasa. Hasil penerjemahan yang berbeda, tentunya akan menimbulkan pemaknaan atau persepsi yang berbeda pula bagi penutur bahasanya, dari persepsi yang berbeda ini, maka muncullah emosi berupa tindakan yang berbeda pula.

Kajian tentang interaksi bahasa Arab di dalam bahasa Indonesia maupun bahasa Malaysia, pernah dilakukan oleh pengkaji bahasa sebelumnya. Di antaranya adalah penelitian mengenai pengaruh dan pemaknaan kamus-kamus Arab-Melayu di Malaysia yang dapat meningkatkan pemahaman yang baik dalam mengkaji al-Qur'an (Alfa, Dollah, \& Abdullah, 2015). Penerjemahan bahasa Arab ke dalam bahasa Melayu di Malaysia dengan menggunakan penilaian historis dan 
kontemporer. Hasil dari penelitian ini adalah bahwa praktik penerjemahan juga memengaruhi penggunaan bahasa nasional, dan membantu bahasa lokal dalam berinteraksi dengan bahasa asing untuk kepentingan ekonomi, budaya, ideologi, dan politik, sehingga sekolah-sekolah dasar dan sekolah agama di masjid-masjid Malaysia menggunakan bahasa Arab (Mat, Azman Che. 2010). Tingginya jumlah kata serapan bahasa Arab ke dalam bahasa Malaysia yaitu sebanyak 70,4\%, dapat membantu tenaga pendidik dalam mengajarkan ilmu agama Islam (Zaidan, Azlina, Zailaini, \& Ismail, 2015).

Persoalan tentang terjemah al-Qur'an ke dalam bahasa asing lainnya, seperti bahasa Inggris dan bahasa Belanda, telah banyak dikaji oleh peneliti terdahulu. Pada al-Qur'an terjemah bahasa Inggris, ditemukan istilah-istilah yang tidak memiliki padanan langsung dalam bahasa Inggris. Penerjemahan kosa kata al-Qur'an ke dalam bahasa Inggris cenderung hanya memberikan arti yang mendekati, namun tidak memiliki unsur makna yang serupa. Kata taqwā diterjemahkan dengan piety, kufr: disbelief, haq: truth , ma'rüf: charity, munkar: wrong, ghaib diterjemahkan dengan kata unseen/unknown, zakāh: alms giving, dan täwbah: repentance (Ali, et.al, 2012). Kajian alQur'an berbahasa Belanda De Heilige Queran yang dilakukan oleh (Bustam \& Astari, 2018) menemukan bahwa al-Qur'an terjemah bahasa Belanda cenderung menghindari pemaknaan kosa kata di dalam al-Qur'an yang berdimensi metafisik dan penerjemahannya mengarah kepada رفع الله kasionalitas yang bisa diterima oleh akal dan ilmiah, sebagai contoh, penerjemahan kata dalam konteks kisah nabi Isa pada surah Annisa: 158, maka pada De Heilige Queran diterjemahkan dengan 'ferheaven' yang berarti 'memuliakan'. Hal ini didasari secara rasional bagi kalangan Belanda seseorang yang diangkat ke atas belum dapat diterima secara akal, sehingga makna yang digunakan dalam terjemah De Heilige Quer an, yaitu 'memuliakan' (Astari \& Bustam, 2019). Selain pilihan padanan kata, berdampak pula pada perubahan penggunaan gaya bahasa penerjemah dalam menerjemahkan al-Qur'an, meskipun penerjemah masih menerapkan prinsipprinsip terjemah al-Quran (Abd. Rahman, 2014). Kajian terdahulu menganjurkan adanya kebutuhan tim pakar bahasa dan orang- orang yang kompeten untuk menerjemahkan al-Qur'an dalam sebuah kolokasi dan kelompok (Kamalie, 2011).

Adapun lingkup penelitian ini dibatasi pada kata-kata yang mengalami perbedaan makna pada terjemah al-Qur'an versi online Kemenag RI dan Jakim tahun 2017. Hasil penelusuran ditemukan perbedaaan makna pada ayat-ayat terkait wanita. Kementrian pembangunan wanita (dalam istilah Indonesia: Menteri pemberdayaan wanita) sangat memperhatikan hak-hak kaum yang dituangkan dalam undang-undang negara. Artikel ini bertujuan untuk mendeskripsikan perbedaan konsep makna antara kosakata dalam kamus bahasa Arab-Indonesia dengan ArabMelayu/Malaysia, konsep makna terjemah al-Qur'an versi bahasa Indonesia dan Malaysia dan menjelaskan faktor yang memengaruhi perbedaan konsep makna tersebut. Berdasarkan pemaparan di atas, artikel ini berupaya untuk melanjutkan kajian sebelumnya, bagaimana perbedaan konsep makna antara kosakata terjemah al-Qur'an versi bahasa Indonesia dan Malaysia serta menjelaskan faktor yang memengaruhi perbedaan konsep makna kedua bahasa tersebut.

\section{Metode}

Penelitian ini bersifat deskriptif kualitatif yang menganalisis data secara induktif. Untuk itu, diperlakukan dalam tiga tahapan, yakni; tahap penyediaan (pengumpulan) data, tahap analisis data dan tahap penyajian hasil analisis data. Objek material penelitian ini adalah: kamus al-Wafi ArabIndonesia 2015 (Al-Mujahid, 2016), kamus Diwan Arab-Malaysia 2016 (Bin Khalid, 2016); terjemah al-Qur'an versi on-line ayat-ayat tentang wanita pada Jakim (Jabatan Kemajuan Islam Malaysia) dan Kemenag RI (Kementrian Agama Republik Indonesia) pada Januari 2017.

Adapun objek formalnya adalah: konsep makna antara kosakata dalam kamus ArabIndonesia dengan Arab-Malaysia, konsep makna terjemah al-Qur'an versi bahasa Indonesia dan Malaysia serta menjelaskan faktor yang memengaruhi perbedaan konsep makna tersebut. 


\section{Arabi : Journal of Arabic Studies}

Penyediaan data diawali dengan pengumpulan data berupa: kosakata yang mengalami perbedaan terjemah di dalam al-Qur'an versi bahasa Indonesia dan terjemah al-Qur' an versi bahasa Malaysia. Pengumpulan data ini dilakukan dengan metode simak (Sudaryanto 2015), dengan teknik catat, yaitu mencatat data objek penelitian dari ragam tulisan, dan teknik libat cakap (wawancara) dengan penutur bahasa Malaysia kemudian dilanjutkan dengan klasifikasi data.

Metode yang digunakan dalam upaya menemukan kaidah dalam tahap analisis data adalah metode padan dan metode agih (Sudaryanto 2015). Pada tahapan ini, data dianalisis dengan menggunakan metode padan, dengan teknik dasarnya, yaitu teknik pilah unsur penentu (teknik PUP). Adapun alatnya ialah daya pilah yang bersifat mental yang dimiliki oleh peneliti. Adapun teknik lanjutannya yaitu: 1. teknik HBS (teknik hubung banding menyamakan); 2. teknik HBB (teknik hubung memperbedakan); 3. teknik HBSP (teknik hubung banding menyamakan hal pokok). Penggunaan metode padan translasional (dalam penelitian bahasa) digunakan dalam penelitian ini sebagai alat penentu bahasa lain atau langue lain untuk membandingkan unsur-unsur maknanya untuk mendapatkan konsep makna.

Setelah data dianalisis berdasarkan konsep-konsep yang sesuai secara semantis, maka pada tahapan berikutnya, untuk melihat perbedaan makna dari masing-masing kosakata, digunakan metode analisis komponen makna (component analysis, tahtilul mukawwināt). Langkah berikutnya adalah dengan memanfaatkan kompetensi penulis serta menanyakan kembali kepada informan (native speaker).

\section{Pembahasan}

Makna merupakan kumpulan dari unsur-unsur makna yang terdapat pada kata, dapat dipahami maksudnya sehingga sesuai dalam konteks penggunanya. Untuk mendeskripsikan perbedaan konsep makna antara kosakata pada terjemah al-Qur'an versi bahasa Indonesia dan Malaysia serta menjelaskan faktor yang memengaruhi perbedaan konsep makna tersebut, maka diperlukan seperangkat teori makna, antara lain: teori terjemah, makna leksikal, makna kontekstual; yang terdiri dari konteks bahasa, konteks situasi, dan konteks budaya, serta pendekatan kontrastif untuk dapat mengungkapkan perbedaan budaya antara budaya bahasa pertama dan bahasa kedua (Nur, Tajudin 2018), adapun uraiannya sebagai berikut:

a. Teori terjemah

Beberapa keterampilan yang harus dimiliki para ahli bahasa antara lain:1) memahami konten dari teks sumber (Sundari, Hanna, and Rina Husnaini Febriyanti 2017). 2) pengetahuan akan budaya bahasa sumber dan bahasa sasaran, karena dalam penerjemahan, alih bahasa berperan sebagai mediator budaya yang dapat menginterpretasikan kandungan makna bahasa sumber dialihkan ke dalam bahasa sasaran (Wang, Caiwen 2017). Aspek linguistik dan budaya dari terjemahan dapat saling melengkapi. Perbedaan dalam bahasa sumber dan bahasa target, budaya mungkin memerlukan informasi tambahan dalam teks target yang menjelaskan fakta-fakta dan gagasan-gagasan yang tidak diketahui oleh reseptor (Komissarov, Vilen N 1991). Jika pengetahuan tersebut hilang karena perbedaan budaya, itu harus diberikan kompensasi bagi penerjemah yang menerjemahkan arti kata-kata pesan asli ke dalam budaya mereka (Komissarov, Vilen N. 1991). Adanya pergeseran makna dari penerjemahan teks sumber ke dalam teks sasaran/ pergeseran tertentu dapat memengaruhi penerimaan teks dalam budaya target(Wyszyńska, Joanna. 2017).

b. Makna leksikal

Makna leksikal adalah makna dasar, makna yang bersumber dari kamus. Ada tiga karakteristik makna leksikal menurut para linguistik kontemporer, yaitu: 1) umum, maksudnya, makna kata yang terdapat dalam kamus bersifat umum, belum menunjukkan kespesifikan makna. Konteks kalimat yang dapat membatasi dan mengikat makna yang umum tersebut; 2) banyak dan bermacam-macam, hal ini karena kata bisa masuk dalam berbagai macam konteks yang berbedabeda; 3) tidak tetap, hal ini karena makna suatu kata dapat berubah-ubah sesuai dengan konteks yang melatarbelakanginya (Haidar, Farid 'Awadh 2005). 


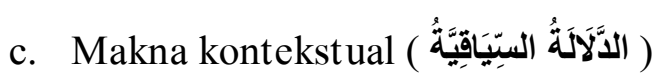

Makna kontekstual adalah makna yang terikat, yang terdapat dalam suatu konteks. Makna konteks dapat juga berkenaan dengan situasinya, yakni tempat, waktu, dan lingkungan penggunaan bahasa tersebut (Haidar, Farid 'Awadh 2005). Para linguis Arab dahulu telah mengerti dan memahami besarnya peran yang dimainkan oleh konteks dalam menentukan makna, al-Jurjani misalnya, dalam bukunya Dalâ'il al-i'jâz menyatakan bahwasanya kosakata dibuat tidak hanya untuk mengetahui makna dasarnya saja (terlepas dari konteks), tetapi disusun dan dirangkai dengan kata lainnya, sehingga dapat diketahui makna kata itu dalam kalimat (Matsna, 2016).

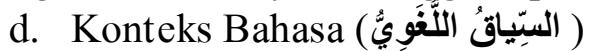

Konteks bahasa adalah makna yang dihasilkan jika suatu kata telah tersusun dengan katakata lainnya dalam suatu kalimat, sehingga menimbulkan makna khusus. Menurut Nasim 'Aun dalam bukunya Alsuniyyah Muhadharat fi 'Ilm Dalalah bahwa makna kamus berbeda dengan makna dalam suatu konteks, karena makna kamus bermacam-macam dan mengandung kemungkinan-kemungkinan, sedangkan makna dalam suatu konteks mempunyai batasan dan tidak bermakna ganda (Matsna, Moh 2016). Contohnya, kata (رأس) secara leksikal berarti bagian tubuh dari leher ke atas, dalam konteks, maka bisa bermakna: puncak (رأس الجبل) pذأس (رل) permulaan الستّنة pangkal (رأس كل خطيئة).

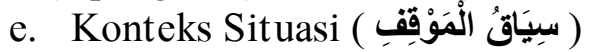

Untuk konteks situasi, yaitu makna yang berkaitan dengan waktu dan tempat berlangsungnya suatu pembicaraan berkaitan dengan pertanyaan kapan, di mana, dan dalam situasi apa ujaran itu diucapkan. Tempat waktu dan kondisi memiliki pengaruh terhadap pemaknaan sebuah kalimat. Para linguis kontemporer menegaskan bahwa untuk mengetahui makna kata dengan benar dan tepat, harus dengan menganalisis konteks yang melatarinya, seperti lingkungan di mana kata tersebut diucapkan, kemudian penutur itu sendiri; bagaimana intonasi pengucapan kata (Matsna, Moh 2016). Umar menambahkan dalam konteks situasi ini, adanya kesamaan nilai antar penutur, dan kalimat-kalimat yang melatarbelakangi pembicaraan (Umar, Ahmad Mukhtar 1998).

\section{f. Konteks Budaya ( السياق الثقافي )}

Dalam pembahasan ini, penggunaan kata yang sama dalam menerjemahkan Al-Qur'an pada kedua bahasa, belum tentu memiliki kesamaan nilai bagi penutur bahasa Malaysia dan Indonesia. Begitu pula perbedaan padaan kata, belum tentu memiliki perbedaan nilai.

Konteks budaya adalah keseluruhan makna yang terdapat dalam budaya tertentu. Pada konteks kebudayaan, penutur dan penulis menggunakan bahasa dalam banyak konteks atau situasi khusus. Konteks budaya adalah lingkungan budaya dan masyarakat yang memungkinkan suatu kata digunakan (Umar, Ahmad Mukhtar 1998), seperti kata (جذر/root/akar) di lingkungan petani punya makna tersendiri, begitu juga di kalangan linguis dan ilmuwan matematika. Di kalangan petani bermakna akar tumbuhan/tanaman. Di kalangan linguis bermakna akar kata. Di kalangan ilmuwan matematika bermakna lambang $(\sqrt{ })$.

Pada artikel ini, teori ini juga digunakan untuk menganalisis konteks budaya di Malaysia dan Indonesia sehingga memengaruhi perbedaan pemilihan kata dalam terjemahan al-Qur'an.

\section{Analisis Semantik Terjemah Ayat-ayat tentang Wanita dalam Terjemah Al-Qur'an versi Jakim dan Kemenag RI}

a. Makna kata قرب dalam bahasa Malaysia dan bahasa Indonesia

Kata قَرَبَ - يَقَرَبُ Maknanya dalam kamus Diwan Arab-Malaysia (AM) yaitu: 'menghampirinya, menyentuhnya'. Dalam kamus bahasa Malaysia (KBM), kata 'hampiri' berarti: 'dekati', rapati'. Menghampiri berarti: 'datang atau pergi berdekatan dengan; mendekati, merapati'. Dalam konteks waktu, kata 'hampir' bermakna: 'tidak lama lagi, sebentar lagi, sekejap lagi, sedikit masa lagi'. 


\section{Arabi : Journal of Arabic Studies}

Pada kamus al-Wafi Arab-Indonesia memiliki makna: 'mendekati'. Adapun komponen makna kedua kata ini yaitu:

Tabel 1. Komponen makna 'hampiri' dan 'dekati'

\begin{tabular}{lcc}
\hline \multicolumn{1}{c}{ Unsur Makna } & Kata 'hampiri' & Kata 'dekati' \\
\hline datang atau pergi berdekatan dengan & $\sqrt{ }$ & $\sqrt{ }$ \\
\hline mendekati & $\sqrt{ }$ & $\sqrt{ }$ \\
\hline Merapati & $\sqrt{ }$ & $\sqrt{ }$ \\
\hline berdekatan satu sama lainnya & $\sqrt{ }$ & $\sqrt{ }$ \\
\hline jaraknya dekat & $\sqrt{ }$ & $\sqrt{ }$ \\
\hline berantonim dengan jauh & $\sqrt{ }$ & $\sqrt{ }$ \\
\hline memiliki makna waktu & $\sqrt{ }$ & $\sqrt{ }$ \\
\hline hampir sampai pada & $\sqrt{ }$ & \\
\hline hampir serupa dengan; mirip & $\sqrt{ }$ & \\
\hline
\end{tabular}

Arti 'dekat' dalam bahasa Malaysia, menunjukkan makna 'di dalam' yang biasa terdengar dalam ucapan penutur bahasa Malaysia, kata 'dekat' disingkat menjadi 'kat'. Sebagai contoh pada kalimat: "kamu kat mana?" "Aku kat umah". Maksud dari kata 'kat' di sini ialah dekat yang berarti di dalam. Berbeda dengan Bahasa Indonesia, dekat rumah berarti berada jarak dekat dari rumah bukan bermakna di dalam rumah.

Berdasarkan analisis komponen makna di atas, maka kata 'hampiri' dan 'dekati' memiliki unsur makna yang sama. Pada konteks masing-masing bahasa, terdapat perbedaan penggunaan yaitu pada reduplikasi kata 'hampir' menjadi 'hampir-hampir', maka tidak dapat digantikan dengan 'dekat-dekat'. Akan tetapi, dalam bahasa Indonesia, kata hampir-hampir tetap digunakan untuk menunjukkan makna 'hampir saja atau 'kurang sedikit'. Begitu pula pada kalimat nomor 9 di bawah ini, 'sudah hampir siap' memiliki rasa bahasa yang sama dalam bahasa Indonesia, yaitu bermakna 'sudah hampir selesai'. Adapun penggunaan kata 'hampiri' dalam bahasa Malaysia dan 'dekati' dalam bahasa Indonesia adalah sebagai berikut:

Tabel 2. Penggunaan kata 'hampiri'

\begin{tabular}{|c|c|c|c|}
\hline No. & $\begin{array}{l}\text { Kata 'hampiri' dalam bahasa } \\
\text { Malaysia }\end{array}$ & Konsep makna & $\begin{array}{l}\text { Padanan dalam bahasa } \\
\text { Indonesia }\end{array}$ \\
\hline 1. & kedai yang berhampiran & sama & toko yang berdekatan \\
\hline 2. & kedai itu hampir & sama & toko itu dekat \\
\hline 3. & dia menghampiri pengemis itu & sama & $\begin{array}{l}\text { dia mendekati pengemis } \\
\text { itu }\end{array}$ \\
\hline 4. & $\begin{array}{l}\text { kedai itu berhampiran dengan } \\
\text { rumah saya }\end{array}$ & sama & $\begin{array}{l}\text { kedai itu berdekatan } \\
\text { dengan rumah saya }\end{array}$ \\
\hline 5. & dia menghampiri saya & sama & $\begin{array}{l}\text { dia datang mendekati } \\
\text { saya }\end{array}$ \\
\hline 6. & $\begin{array}{l}\text { saya menghampirkan buku itu } \\
\text { kepada dia }\end{array}$ & sama & $\begin{array}{l}\text { saya mendekatkan buku } \\
\text { kepada dia }\end{array}$ \\
\hline 7. & $\begin{array}{l}\text { ia telah berupaya } \\
\text { menghampiri pujaan hatinya } \\
\text { itu }\end{array}$ & sama & $\begin{array}{l}\text { Ia telah berusaha } \\
\text { mendekati pujaan hatinya } \\
\text { itu }\end{array}$ \\
\hline \multirow[t]{2}{*}{8.} & \multirow{2}{*}{$\begin{array}{l}\text { saya sudah hampir siap } \\
\text { mengerjakan tugas (mahu } \\
\text { siap/sudah mahu selesai) }\end{array}$} & tidak sama & $\begin{array}{l}\text { saya sudah dekat selesai } \\
\text { mengerjakan tugas }\end{array}$ \\
\hline & & sama & $\begin{array}{l}\text { saya sudah hampir selesai } \\
\text { mengerjakan tugas }\end{array}$ \\
\hline \multirow[t]{2}{*}{9.} & \multirow{2}{*}{$\begin{array}{l}\text { saya hampir-hampir } \\
\text { terlanggar kereta (hampir saja } \\
\text { dekat) }\end{array}$} & tidak sama & $\begin{array}{l}\text { saya dekat-dekat } \\
\text { tertabrak mobil }\end{array}$ \\
\hline & & sama & $\begin{array}{l}\text { Saya hampir-hampir } \\
\text { tertabrak mobil }\end{array}$ \\
\hline
\end{tabular}


Berdasarkan penjelasan di atas, maka kata hampiri dan dekati memiliki konsep makna yang sama untuk menerjemahkan kata قَّب , sebagaimana dalam terjemah Q.S.2: 222 versi bahasa Malaysia dan bahasa Indonesia sebagai berikut:

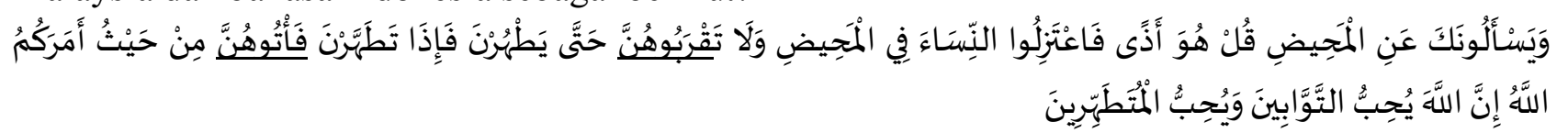

Tabel 3. Terjemah Q.S 2 : 222 versi bahasa Malaysia dan Indonesia

\begin{tabular}{cc}
\hline Terjemah al-Qur'an versi Bahasa Malaysia & Terjemah al-Qur'an versi Bahasa \\
(Jakim) & Indonesia (Kemenag.RI)
\end{tabular}

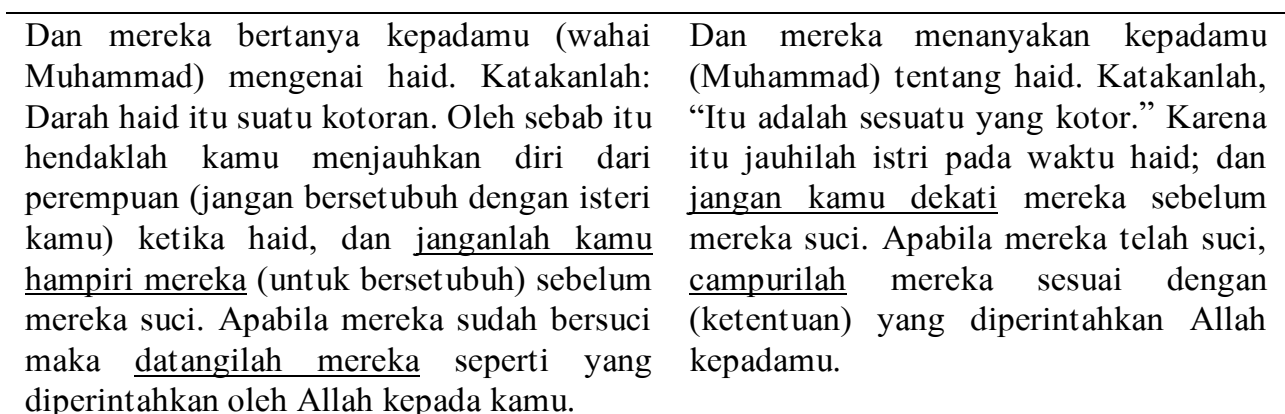

Menurut persepsi penutur bahasa Malaysia, kalimat وَلَ تَقْرَبُوهُنَّ diterjemahkan dengan 'janganlah kamu hampiri mereka' dalam terjemah Jakim di atas, berarti: larangan untuk mendekati istri untuk bersetubuh, namun kata 'hampiri' tidak bisa diganti dengan kata 'sentuh', meskipun dalam kamus Diwan, kata قََبَ berarti : 'menyentuh'. Kata 'hampiri' menunjukkan makna 'hal-hal atau perkara apa saja yang mendekatkan dengan perbuatan', namun jika diganti dengan kata 'sentuh', maka maknanya menjadi: menunjukkan perkara yang lebih mendekati lagi untuk melakukan perbuatan jika dibandingkan dengan kata 'hampiri'. Jadi kata 'menyentuh' memiliki konsep makna yang sama dengan mencampuri, yaitu lebih mendekati istri jika dibandingkan dengan kata 'menghampiri', sehingga dalam terjemah di atas setelah kalimat 'janganlah kamu hampiri' diikuti dengan keterangan (untuk bersetubuh).

Kemudian kalimat فَأَتُوهُنَ pada Jakim diterjemahkan dengan 'datangilah mereka' tidak digunakan kata 'campurilah', sebagaimana dalam terjemah bahasa Indonesia. Pada bahasa Malaysia, kata 'campur' menunjukkan makna: pergaulan antara pria dan wanita yang tidak sah/tidak melalui proses pernikahan, sehingga kata 'campur' dalam konteks ini ini memiliki nilai yang negatif. Berbeda dalam bahasa Indonesia, kata 'campuri' digunakan dalam konteks hubungan suami istri yang sah, dan memiliki nilai emotif yang netral.

Menurut persepsi penutur bahasa Indonesia, kalimat وَلَ تَقْرَبُوهُنَّ pada ayat di atas, diterjemahkan dengan 'jangan kamu dekati mereka. Kata 'mendekati' di sini, menurut persepsi penutur bahasa Indonesia, yaitu: larangan untuk mendekati/berhubungan suami istri (jimak) karena ada kaitannya حَنَّى يَطْهُرْنْ.

Kata 'mendekati di sini untuk menjauhi hal-hal yang mengarah ke jimak, terutama bagi yang tidak bisa menahan hawa nafsunya maka hendaknya menghindari, lebih dijelaskan sampai dia suci. Terkait perlakuan terhadap wanita haid itu juga harus berbeda, karena di masa itu, emosi wanita tidak terkendali. Menurut tafsir al-Misbah makna dari kata وَََا تَقْرَبُوهُنَّ yakni bermakna' jangan dekati' arti dari ayat tersebuat ialah hendaklah kamu menjauhkan diri dari wanita, dalam arti 'tidak bersetubuh', pada waktu mereka mengalami haid, atau pada tempat haid itu keluar. Ini berarti boleh didekati asal bukan pada tempat haid, yakni bukan pada tempat gangguan itu, mendekati di sini adalah mendekati tempat dimana dapat terjadi hubungan seks (Shihab, M. Quraish 2012). 


\section{Arabi : Journal of Arabic Studies}

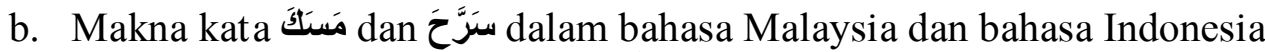

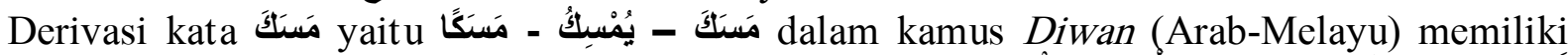

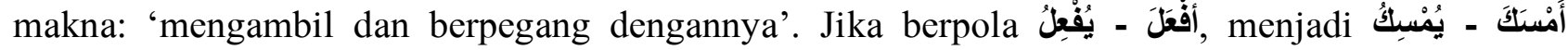
bermakna: 'memegang dengan tangan, menahan daripada menurunkannya' sedangkan dalam kamus Al-Wafi (Arab-Indonesia) memiliki makna:' memegang, berpegang teguh pada sesuatu,

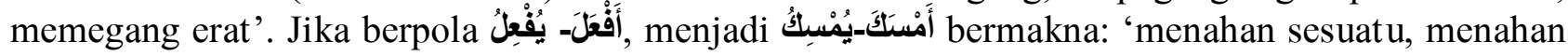
diri dari'.

Dalam bahasa Malaysia, kata 'pegang' ini lazim juga digunakan dalam konteks rujuk, sedangkan 'menahan' dalam bahasa Indonesia yaitu 'menghentikan, mencegah, tidak membiarkan lepas'. Adapun komponen makna kedua kata ini yaitu:

Tabel 4. Penggunaan kata 'pegang'

\begin{tabular}{|c|c|c|c|}
\hline Unsur Makna & $\begin{array}{c}\text { Kata } \\
\text { ‘pegang'dalam } \\
\text { bahasa Malaysia } \\
\end{array}$ & $\begin{array}{c}\text { Kata } \\
\text { ‘pegang'dalam } \\
\text { bahasa Indonesia } \\
\end{array}$ & $\begin{array}{c}\text { Kata 'tahan' } \\
\text { dalam bahasa } \\
\text { Indonesia } \\
\end{array}$ \\
\hline $\begin{array}{lr}\text { menggenggam } & \text { atau } \\
\text { memaut dengan } & \text { tangan; } \\
\text { menjadikan } & \text { tangan } \\
\text { menggenggam } & \\
\end{array}$ & $\sqrt{ }$ & $\sqrt{ }$ & - \\
\hline $\begin{array}{l}\text { mengurus atau memimpin } \\
\text { perusahaan }\end{array}$ & $\sqrt{ }$ & $\sqrt{ }$ & - \\
\hline $\begin{array}{l}\text { tetap berpegang teguh pd } \\
\text { sesuatu sbg pedoman: } \\
\text { sesuatu amanah }\end{array}$ & $\sqrt{ }$ & $\sqrt{ }$ & - \\
\hline patuh pada aturan/janji & $\sqrt{ }$ & $\sqrt{ }$ & - \\
\hline $\begin{array}{l}\text { memiliki makna majazi } \\
\text { rujuk }\end{array}$ & $\sqrt{ }$ & - & - \\
\hline mempunyai & - & $\sqrt{ }$ & - \\
\hline mengemudi/menyetir & - & $\sqrt{ }$ & - \\
\hline menangkap & - & $\sqrt{ }$ & - \\
\hline memakai/menggunakan & - & $\sqrt{ }$ & - \\
\hline menguasai & - & $\sqrt{ }$ & $\sqrt{ }$ \\
\hline menjalankan & - & $\sqrt{ }$ & - \\
\hline $\begin{array}{l}\text { tetap } \\
\text { keadaan/kedudukannya }\end{array}$ & $\sqrt{ }$ & $\sqrt{ }$ & $\sqrt{ }$ \\
\hline menghentikan & - & $\sqrt{ }$ & $\sqrt{ }$ \\
\hline mencegah & - & $\sqrt{ }$ & $\sqrt{ }$ \\
\hline $\begin{array}{l}\text { tidak membiarkan lepas } \\
\text { (terus berlangsung) }\end{array}$ & $\sqrt{ }$ & $\sqrt{ }$ & $\sqrt{ }$ \\
\hline membiarkan tidak terjadi & $\sqrt{ }$ & $\sqrt{ }$ & $\sqrt{ }$ \\
\hline $\begin{array}{l}\text { tidak meneruskan; tidak } \\
\text { menyampaikan }\end{array}$ & - & $\sqrt{ }$ & $\sqrt{ }$ \\
\hline
\end{tabular}

Berdasarkan analisis komponen makna di atas, maka di dalam kata 'pegang' dalam bahasa Malaysia tidak memiliki unsur makna yang beragam sebagaimana unsur makna kata 'pegang' dalam bahasa Indonesia. Penggunaan kata pada konteks masing-masing bahasa, terdapat persamaan penggunaan, yaitu sama-sama memiliki unsur makna: 'tetap, tidak membiarkan untuk lepas, membiarkan tidak terjadi, tidak meneruskan; tidak menyampaikan'. Adapun persamaan penggunaan kata 'pegang' dan 'tahan' dalam kedua bahasa adalah sebagai berikut;

Tabel 5. Persamaan penggunaan kata 'pegang' dan 'tahan'

\begin{tabular}{lcl}
\hline \multicolumn{1}{c}{ Kata 'pegang' dalam bahasa } & Konsep & Padanan dalam bahasa Indonesia \\
Malaysia & sama & $\begin{array}{l}\text { kami menahan kuda itu agar tidak } \\
\text { berlari }\end{array}$ \\
\hline $\begin{array}{l}\text { kami memegangi kuda itu agar } \\
\text { tidak berlari }\end{array}$ & & \\
\hline
\end{tabular}


Demikian pula kata pegang dalam BM dan BI juga memiliki perbedaan penggunaan dalam kalimat sebagai berikut:

Tabel 6. Perbedaan penggunaan kata 'pegang'

\begin{tabular}{lcl}
\hline $\begin{array}{l}\text { Kata 'pegang' dalam bahasa } \\
\text { Malaysia }\end{array}$ & $\begin{array}{c}\text { Konsep } \\
\text { makna }\end{array}$ & Padanan dalam bahasa Indonesia \\
\hline $\begin{array}{l}\text { mereka berjalan dengan } \\
\text { berpegangan tangan }\end{array}$ & sama & $\begin{array}{l}\text { mereka berjalan dengan } \\
\text { berpegangan tangan }\end{array}$ \\
\hline $\begin{array}{l}\text { beliau telah memegang jawatan } \\
\text { pengurus di firma itu selama dua } \\
\text { tahun }\end{array}$ & sama & $\begin{array}{l}\text { dia memegang jabatan di } \\
\text { perusahaan }\end{array}$ \\
\hline dia masih memegang amanah itu & sama & dia masih memegang amanah itu \\
\hline ia berpegang pada janji & sama & ia berpegang pada janji \\
\hline $\begin{array}{l}\text { ia adalah pemegang mohor besar } \\
\text { seperti majelis syuro saat } \\
\text { menentukan tgl 1 syawal }\end{array}$ & tidak sama & $\begin{array}{l}\text { ia adalah pemegang keputusan } \\
\text { dalam penentuan tgl 1 syawal }\end{array}$ \\
\cline { 2 - 3 } & sama & $\begin{array}{l}\text { ia adalah orang yang bertanggung } \\
\text { jawab dalam penent uan tgl 1 }\end{array}$ \\
\hline $\begin{array}{l}\text { suami bolehlah kamu pegang } \\
\text { mereka (rujuk) }\end{array}$ & sama & $\begin{array}{l}\text { suami bolehlah kamu tahan mereka } \\
\text { (rujuk) }\end{array}$ \\
\hline siti pegang watak antagonis & sama & siti memegang peran antagonis \\
\cline { 2 - 3 } & tidak sama & siti memerankan antagonis \\
\hline $\begin{array}{l}\text { dia pegang prinsip hingga nafas } \\
\text { terakhir }\end{array}$ & sama & dia berpegang pada prinsip \\
\hline saya tidak punya wang & tidak sama & saya tidak pegang uang \\
\hline $\begin{array}{l}\text { Saya tidak berani memandu } \\
\text { kereta }\end{array}$ & tidak sama & $\begin{array}{l}\text { dia tidak berani memegang stir } \\
\text { mobil }\end{array}$ \\
\hline
\end{tabular}

Berdasarkan penjelasan di atas, maka kata 'pegang' dan 'tahan' memiliki konsep makna yang sama untuk menerjemahkan kata أَمْنَكُ , karena sama-sama memiliki unsur makna: tidak membiarkan lepas, membiarkan tidak terjadi perceraian, sebagaimana dalam terjemah Q.S. 2:231 versi bahasa Malaysia dan bahasa Indonesia sebagai berikut:

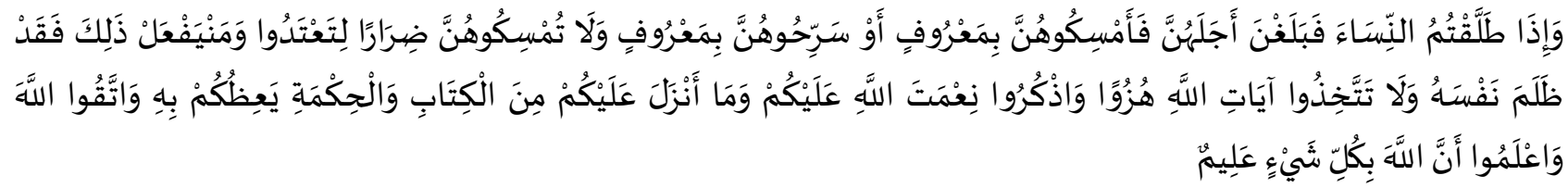

Tabel 7. terjemah Q.S. 2: 231 versi bahasa Malaysia dan bahasa Indonesia

\begin{tabular}{|c|c|}
\hline $\begin{array}{c}\text { Terjemah al-Qur'an versi Bahasa Malaysia } \\
\text { (Jakim) }\end{array}$ & $\begin{array}{c}\text { Terjemah al-Qur'an versi Bahasa } \\
\text { Indonesia (Kemenag RI) }\end{array}$ \\
\hline $\begin{array}{l}\text { Dan apabila kamu menceraikan isteri-isteri } \\
\text { kamu kemudian mereka hampir tempoh } \\
\text { iddahnya, maka bolehlah kamu pegang } \\
\text { mereka (rujuk) dengan baik, atau lepaskan } \\
\text { mereka dengan baik. Dan janganlah kamu } \\
\text { rujuk mereka untuk memberi mudarat, }\end{array}$ & $\begin{array}{l}\text { Dan apabila kamu menceraikan istri-istri } \\
\text { (kamu), lalu sampai (akhir) idahnya, } \\
\text { maka tahanlah mereka dengan cara yang } \\
\text { baik, atau ceraikanlah mereka dengan } \\
\text { cara yang baik (pula). Dan janganlah } \\
\text { kamu tahan mereka dengan maksud }\end{array}$ \\
\hline $\begin{array}{l}\text { kerana kamu hendak melakukan kezaliman; } \\
\text { dan sesiapa yang melakukan demikian maka } \\
\text { sesungguhnya dia menganiaya dirinya } \\
\text { sendiri. Dan janganlah kamu menjadikan } \\
\text { ayat-ayat hukum Allah itu sebagai } \\
\text { permainan. }\end{array}$ & $\begin{array}{l}\text { jahat untuk menzalimi mereka. } \\
\text { Barangsiapa melakukan demikian, maka } \\
\text { dia telah menzalimi dirinya sendiri. Dan } \\
\text { janganlah kamu jadikan ayat-ayat Allah } \\
\text { sebagai bahan ejekan. ketahuilah bahwa } \\
\text { Allah Maha Mengetahui segala sesuatu. }\end{array}$ \\
\hline
\end{tabular}

Menurut persepsi penutur bahasa Malaysia, kalimat فَاََمْنِكُونَنَ diterjemahkan dengan: 'maka bolehlah kamu pegang mereka.', kata 'pegang' di sini berarti: 'kembali pada ikatan tali pernikahan. Kata 'pegang' untuk rujuk tidak biasa digunakan oleh sebagian masyarakat Malaysia, 


\section{Arabi : Journal of Arabic Studies}

yang biasa digunakan, yaitu kata rujuk atau kembali, seperti pada kalimat yang menyatakan suami merujuk istri berikut ini:

-suami: "awak kembali ke saya"

Kata 'pegang' dapat digantikan dengan kata 'tahan' atau 'halang'untuk tidak melepaskan ikatan pernikahan. Untuk kata سَرََّ, pada konteks ayat di atas diterjemahkan dengan 'lepaskan'.Penggunaan kata 'lepaskanlah' menunjukkan makna yang lebih halus daripada kata 'ceraikanlah'. Kata tersebut juga memiliki makna sama dengan kata 'ceraikanlah'.

Budaya masyarakat Malaysia, dalam konteks perceraian, misalnya dalam kalimat: Ia lepas dari suaminya, maka juga dapat bermakna: ia lari dari suaminya. Kata 'lepaskan', tidak bisa diganti dengan kata 'mengirim' atau 'menghantar'. Kata 'lepaskan' di sini bermakna 'menceraikan atau membebaskan'. Kata lepaskan merupakan kiasan atau sindiran. Selain kata 'ceraikan', kata 'lepaskan' juga digunakan untuk kiasan bagi suami ingin menceraikan istri dalam budaya masyarakat Malaysia. Contoh ungkapan istri kepada suami jika minta diceraikan: 'tolong lepaskan saya'.

Menurut persepsi penutur bahasa Indonesia, kalimat فَأَمْنِكُوهُنَّ diterjemahkan dengan: 'maka tahanlah mereka'kata 'tahanlah' di sini berarti: menahan untuk memutuskan tali pernikahan atau rujuk. Untuk kata سَرََّ. Pada kamus al-Wafi berarti: 'melepaskan, membebaskan', tapi pada konteks ayat di atas diterjemahkan dengan 'ceraikanlah', karena dalam budaya Indonesia, tidak menggunakan kata 'lepaskan atau bebaskan' untuk menunjukkan makna menceraikan. Dalam budaya Indonesia untuk kiasan cerai ini selain dengan kata menceraikan, kiasan halus yaitudengan kata 'pulang ke rumah orang tua' atau 'sudah tidak suka lagi, sedangkan untuk menunjukkan kembali terjalin ikatan yaitu dengan kata 'rujukilah'.

Selanjutnya, kata tahanlah memiliki makna: 'menghentikan, mencegah'. Dalam penjelasan tafsir al-Misbah kata فَأَمْنِكُوهُنَ diartikan sebagai kata 'rujukilah', makna kata tersebut ialah kembalinya suami kepada istri yang ditalak, talak satu atau dua, ketika istri masih pada tempoh iddah, jadi kata 'tahan' dan 'rujuk' memiliki maksud yang sama, yaitu sama-sama kembali (rujuk).

c. Makna kata عَضَ dalam bahasa Malaysia dan bahasa Indonesia.

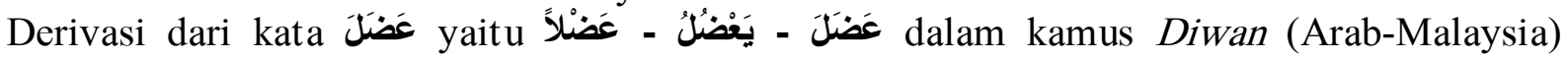
memiliki makna: 'menjadi susah, menyempitkan, menghalangi', sedangkan dalam dalam kamus alWafi (Arab-Indonesia) memiliki makna: 'memukul, otot seseorang'. Pada kamus al-Ma'any kategori Qur'an words kata تَغْضُكُوهُنْ berarti 'kamu menghalangi mereka', kamu menyusahkan

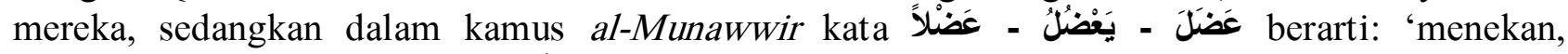
mempersempit dan pada kata عَضَ memiliki makna: 'mencegah, menghalang-halangi'. Kaitan makna antara kata 'memukul dan menghalang-halangi' di sini yaitu bersikap terang-terangan untuk menghalangi, karena wanita cenderung takut jika melihat seorang melakukan tindakan fisik. Adapun komponen makna kedua kata ini yaitu:

Tabel 8. Komponen makna kata 'menahan' dan 'menghalangi'

\begin{tabular}{|c|c|c|}
\hline unsur makna & $\begin{array}{c}\text { kata 'menahan'/ bahasa } \\
\text { Malaysia }\end{array}$ & $\begin{array}{c}\text { kata 'menghalangi'/ } \\
\text { bahasa Indonesia }\end{array}$ \\
\hline $\begin{array}{l}\text { menahan sesuatu supaya } \\
\text { tidak dapat bergerak }\end{array}$ & $\sqrt{ }$ & $\sqrt{ }$ \\
\hline $\begin{array}{l}\text { menahan sesuatu agar tidak } \\
\text { mengalir }\end{array}$ & $\sqrt{ }$ & - \\
\hline $\begin{array}{l}\text { tidak membenarkan } \\
\text { seseorang melakukan } \\
\text { sesuatu }\end{array}$ & $\sqrt{ }$ & $\sqrt{ }$ \\
\hline menegah; melarang & $\sqrt{ }$ & $\sqrt{ }$ \\
\hline menutupi & - & $\sqrt{ }$ \\
\hline menghentikan & $\sqrt{ }$ & $\sqrt{ }$ \\
\hline mencegah; menanggulangi: & - & $\sqrt{ }$ \\
\hline tidak membiarkan terus & $\sqrt{ }$ & $\sqrt{ }$ \\
\hline
\end{tabular}

Vol. 5 No. 1 | $72-78$

Copyright @ 2020 | ARABI | p-ISSN 2548-6616 | e-ISSN 2548-6624 
Arabi : Journal of Arabic Studies

\begin{tabular}{lcc}
\hline berlangsung & $\sqrt{ }$ & \multicolumn{1}{l}{} \\
\hline $\begin{array}{l}\text { tidak meneruskan; tidak } \\
\text { menyampaikan: }\end{array}$ & $\sqrt{ }$ & $\sqrt{ }$ \\
\hline tidak melanjutkan & - & $\sqrt{ }$ \\
\hline $\begin{array}{l}\text { tidak mengizinkan (untuk } \\
\text { pergi, berangkat }\end{array}$ & $\sqrt{ }$ & $\sqrt{ }$ \\
\hline $\begin{array}{l}\text { mengurung (memenjarakan) } \\
\text { untuk sementara }\end{array}$ & $\sqrt{ }$ & \\
\hline $\begin{array}{l}\text { tidak memberikan sesuatu } \\
\text { gaji dan sebagainya) kepada } \\
\text { yang berhak }\end{array}$ & & $\sqrt{ }$ \\
$\begin{array}{l}\text { menyimpan untuk } \\
\text { persediaan }\end{array}$ & - & $\sqrt{ }$ \\
\hline menderita; menanggung: & $\sqrt{ }$ \\
\hline $\begin{array}{l}\text { menguatkan diri supaya } \\
\text { tahan }\end{array}$ & $\sqrt{ }$ & $\sqrt{ }$ \\
\hline
\end{tabular}

Pada bahasa Malaysia 'menghalangi'. Kata 'menghalangi' memiliki makna menahan hanya saat kejadian, sebagai contoh:

- Aku halang kau naik motor maknanya: 'dia menghalangi lelaki itu mengendarai motor hanya pada waktu itu, besok pagi dia sudah bisa mengendarai motor lagi'.

Berbeda dengan kata 'menahan', kata 'menghalangi; memiliki durasi waktu lama, contoh:

- Aku tahan kamu dari naik motor maknanya: 'dia tahan kamu sampai dia melepaskan kamu, setelah terlepas baru bisa naik motor. Itulah perbedaan pemilihan kata menahan dan menghalangi.

Berdasarkan analisis komponen makna di atas, maka penggunaan kata 'menahan' dan 'menghalangi' pada masing-masing bahasa, terdapat persamaan penggunaan yaitu sama-sama memiliki unsur makna: 'tidak membenarkan seseorang melakukan sesuatu, tidak membiarkan terus berlangsung, tidak meneruskan'. Pada bahasa Indonesia, digunakan kata menghalangi karena pada kata itu terdapat unsur makna 'berupaya untuk membatalkan'. Adapun penggunaan kata 'menahan' dan 'menghalangi' dalam kedua bahasa, sebagai berikut:

Tabel 9. Penggunaan kata 'menahan' dan 'menghalangi'

\begin{tabular}{|c|c|c|}
\hline $\begin{array}{l}\text { Kata 'menahan' dalam bahasa } \\
\text { Malaysia }\end{array}$ & $\begin{array}{c}\text { Konsep } \\
\text { makna }\end{array}$ & Padanan dalam bahasa Indonesia \\
\hline $\begin{array}{l}\text { beting pasir itu menahan air } \\
\text { mengalir ke laut }\end{array}$ & sama & $\begin{array}{l}\text { beting pasir itu menghalangi air } \\
\text { mengalir ke laut }\end{array}$ \\
\hline $\begin{array}{l}\text { hulubalang melaka itu pun } \\
\text { ditahan oleh bendahara, tiada } \\
\text { diberinya upah }\end{array}$ & tidak sama & $\begin{array}{l}\text { hulubalang melaka itu pun dihalangi } \\
\text { oleh bendahara, tidak diberi upah }\end{array}$ \\
\hline $\begin{array}{l}\text { dia menahan motor itu agar } \\
\text { tidak bergerak }\end{array}$ & tidak sama & $\begin{array}{l}\text { dia menghalangi motor itu agar tidak } \\
\text { bergerak }\end{array}$ \\
\hline menahan air masuk ke rumah & sama & menghalangi air masuk ke rumah \\
\hline $\begin{array}{l}\text { dia menahan dirinya untuk tidak } \\
\text { mengeluarkan kata-kata kesat }\end{array}$ & tidak sama & $\begin{array}{l}\text { dia menghalangi dirinya untuk tidak } \\
\text { mengeluarkan kata-kata buruk }\end{array}$ \\
\hline $\begin{array}{l}\text { keluarganya tidak sanggup lagi } \\
\text { menahan rasa malu }\end{array}$ & tidak sama & $\begin{array}{l}\text { keluarganya tidak sanggup lagi } \\
\text { menghalang rasa malu }\end{array}$ \\
\hline
\end{tabular}

Berdasarkan penjelasan di atas, maka kata menahan dan menghalangi memiliki konsep makna yang sama untuk menerjemahkan kata tran, sebagaimana dalam terjemah QS. 2: 232 versi bahasa Malaysia dan bahasa Indonesia sebagai berikut:

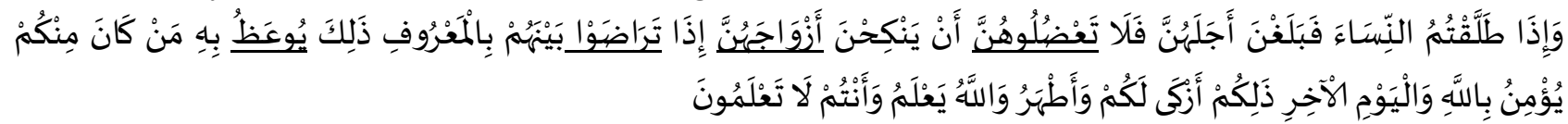




\section{Arabi : Journal of Arabic Studies}

Tabel 10. Terjemah QS. 2: 232 versi bahasa Malaysia dan bahasa Indonesia

Terjemah al-Qur'an versi Bahasa Malaysia(Jakim)
Terjemah al-Qur'an versi Bahasa Indonesia (Kemenag.RI)

\begin{tabular}{|c|c|}
\hline $\begin{array}{l}\text { Dan apabila kamu menceraikan isteri-isteri } \\
\text { kamu, lalu habis iddahnya, maka janganlah } \\
\text { kamu (para wali) menahan mereka daripada } \\
\text { berkahwin semula dengan (bekas) suami } \\
\text { mereka, apabila mereka bersetuju sesama } \\
\text { sendiri dengan cara yang baik. }\end{array}$ & $\begin{array}{l}\text { Dan apabila kamu menceraikan istri-istri } \\
\text { (kamu), lalu sampai idahnya, } \underline{\text { maka }} \\
\text { jangan kamu halangi mereka menikah } \\
\text { (lagi) dengan calon suaminya, apabila } \\
\text { telah terjalin kecocokan di antara } \\
\text { mereka dengan cara yang baik. }\end{array}$ \\
\hline
\end{tabular}

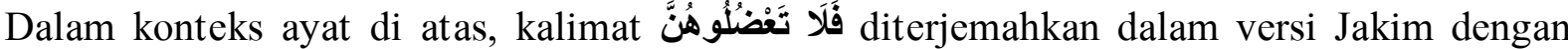
'janganlah kamu (para wali) menahan mereka'. Menurut persepsi penutur bahasa Malaysia, kata 'menahan' di sini, dapat digantikan dengan kata 'menghalangi', namun tidak bisa digantikan dengan 'menjadi susah' yang dapat dimaknai juga dengan 'menyusahkan mereka' dan tidak bisa juga digantikan dengan kata 'menyempitkan', karena berarti 'menyusahkan, menyulitkan'. Adapun contoh penggunaan kalimatnya sebagai berikut:

a) Saya menyulitkan mereka untuk berkahwin bermakna: 'mempersulit urusan pernikahan'.

b) Saya menahan mereka untuk berkahwin bermakna: 'menghalang-halangi untuk menikah'

Pada Al-Qur'an terjemah versi Jakim, kata فَلَا تَعْضُكُوهُنْ berisi larangan untuk menghalahalangi untuk menikah dengan bekas suami atau suami yang pernah menikahi si istri kemudian menceraikannya.

Pada terjemah Jakim, digunakan kata 'calon suami', bukan kata bekas. Kata 'bekas' dalam bahasa Malaysia berarti 'tempat atau wadah dan menunjukkan kesan sesuatu (sesuatu yang meninggalkan bekas).

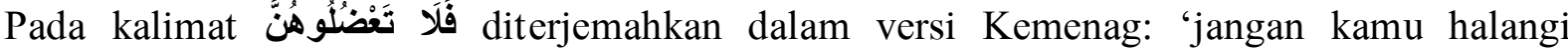
mereka'. Menurut persepsi penutur bahasa Indonesia, bermakna: sikap menghalang-halangi atau menakut-nakuti untuk menikah baik dengan bekas suami atau dengan calon suami yang baru. Hal ini biasa juga budaya rasa malu dari pihak keluarga jika rujuk dengan bekas suami padahal sudah bercerai.

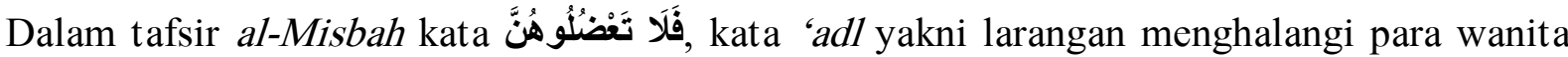
yang telah dicerai itu untuk kawin lagi. Seandainya masa iddahnya belum habis, tentu laranngan tersebut tidak diperlukan karena ketika suami yang menceraikannya masih berhak untuk rujuk kepada istri yang diceraikannya. Kalau sang istri telah habis masa iddahnya dan tidak ada juga halangan lain yang ditetapkan agama, maka janganlah kamu wahai mantan suami dan para wali atau siapapun melakukan 'adl, yakni menghalangi mereka, yaitu para wanita itu, menetapkan sendiri masa depannya menyangkut perkawinan. Siapa saja yang dipilihnya, baik suami-suami mereka yang telah pernah mereka menceraikannya maupun pria lain yang ingin dikawininya yang bakal menjadi suami-suami mereka (Shihab, M. Quraish 2012).

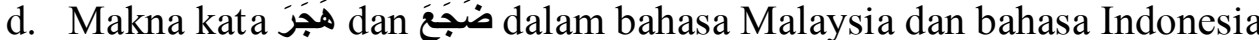

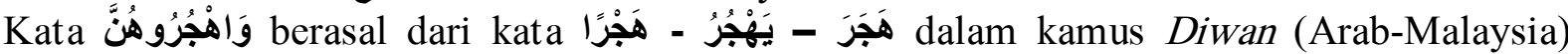
memiliki makna sebagai berikut 'menjauhi, meracau, merekik, meninggalkan', dalam bahasa Malaysia. Makna meracau yaitu: bercakap atau berkata yang bukan-bukan, sedangkan dalam kamus al-Wafi (Arab-Indonesia) memiliki makna meninggalkan sesuatu, meninggalkan seseorang.

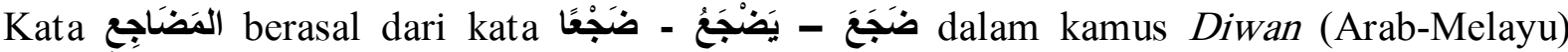
memiliki makna 'berbaring dengan sebelah rusuknya, berpaling, tempat tidur, tempat hujan turun'. Dalam bahasa Malaysia, yang dimaksud dengan sebelah rusuknya yaitu: terus, tidak singgah ke mana-mana, tidak teputus, sedangkan dalam kamus al-Wafi (Arab-Indonesia) memiliki makna 'berbaring, merebah, rebahan, tiduran, tempat berbaring, pembaringan, rebahan, tempat tidur'. 


\section{Arabi : Journal of Arabic Studies}

Pada al-Qur'an tejemah versi Jakim, kata وَاهْجُرُوهُنَ diterjemahkan dengan 'pulaukanlah' sedangkan dalam terjemah versi Kemenag diterjemahkan dengan 'tinggalkanlah'. Adapun komponen makna kata 'pulaukanlah'/BM dan 'tinggalkanlah' dalam BI yaitu:

Tabel 11. Komponen makna kata 'pulaukanlah' dan 'tinggalkanlah'

\begin{tabular}{|c|c|c|}
\hline Unsur Makna & $\begin{array}{l}\text { Kata 'pulaukanlah'/ bahasa } \\
\text { Malaysia }\end{array}$ & $\begin{array}{l}\text { Kata 'tinggalkanlah'/ } \\
\text { bahasa Indonesia }\end{array}$ \\
\hline memisahkan dari seseorang & $\sqrt{ }$ & $\sqrt{ }$ \\
\hline mengasingkan & $\sqrt{ }$ & - \\
\hline $\begin{array}{l}\text { menyisihkan seseorang atau } \\
\text { menyisihkan diri } \\
\text { daripadanya }\end{array}$ & $\sqrt{ }$ & \\
\hline $\begin{array}{l}\text { enggan berurusan dgn } \\
\text { seseorang, sesuatu. }\end{array}$ & $\sqrt{ }$ & $\sqrt{ }$ \\
\hline memboikot & $\sqrt{ }$ & - \\
\hline $\begin{array}{l}\text { membiarkannya tinggal di } \\
\text { tempat, tidak dibawa pergi }\end{array}$ & $\sqrt{ }$ & $\sqrt{ }$ \\
\hline pergi dari; menghindar dari & $\sqrt{ }$ & $\sqrt{ }$ \\
\hline membiarkan lepas & - & $\sqrt{ }$ \\
\hline sudah mendahului, melewati & - & $\sqrt{ }$ \\
\hline $\begin{array}{l}\text { membuang (adat, kebiasaan } \\
\text { buruk, keyakinan) }\end{array}$ & - & $\sqrt{ }$ \\
\hline melalaikan & - & $\sqrt{ }$ \\
\hline
\end{tabular}

Berdasarkan analisis komponen makna di atas, penggunaan kata pulaukanlah biasanya digunakan untuk menunjukkan makna menyisihkan seseorang dalam sesuatu perkara karena faktor kesalahan yang telah dilakukan oleh seseorang. Sebagai contoh: suami akan memulaukan isteri yang nusyuz terhadapnya. Pada kata 'pulaukanlah' dan 'tinggalkanlah' memiliki unsur makna yang berbeda. Penggunaan kata pada konteks masing-masing bahasa, terdapat persamaan penggunaan yaitu sama-sama memiliki unsur makna: 'memisahkan dari seseorang', 'enggan berurusan dengan seseorang, sesuatu', pergi, menghindar dari', maka kata pulaukan memiliki nilai: negatif. Berbeda dengan kata tinggalkan, bersifat netral, dapat positif maupun negatif.

Adapun penggunaan kata 'pulaukanlah' dan dalam kalimat bahasa Malaysia dan 'tinggalkanlah' dalam bahasa Indonesia, sebagai berikut:

Tabel 12. Penggunaan kata 'pulaukanlah' dan 'tinggalkanlah'

\begin{tabular}{lcl}
\hline $\begin{array}{l}\text { Kata 'pulaukan' dalam bahasa } \\
\text { Malaysia }\end{array}$ & $\begin{array}{c}\text { Konsep } \\
\text { makna }\end{array}$ & Padanan dalam bahasa Indonesia \\
\hline $\begin{array}{l}\text { pulaukanlah penjenayah yang } \\
\begin{array}{l}\text { sering menyusahkan kehidupan } \\
\text { kita ini }\end{array}\end{array}$ & sama & $\begin{array}{l}\text { asingkanlahkan terdakwah yang } \\
\text { sering menyusahkan kehidupan kita } \\
\text { ini }\end{array}$ \\
\cline { 2 - 3 } & tidak sama & $\begin{array}{l}\text { tinggalkanlahterdakwah yang } \\
\text { sering menyusahkan kehidupan kita } \\
\text { ini }\end{array}$ \\
\hline $\begin{array}{l}\text { siti dipulaukan oleh keluarganya } \\
\text { kerana telah hamil di luar nikah }\end{array}$ & sama & $\begin{array}{l}\text { siti diasingkan oleh keluarganya } \\
\text { kerana telah hamil di luar nikah }\end{array}$ \\
\cline { 3 - 3 } & & $\begin{array}{l}\text { siti ditinggalkan oleh keluarganya } \\
\text { kerana telah hamil di luar nikah }\end{array}$ \\
\hline
\end{tabular}

Berdasarkan penjelasan di atas, maka kata 'pulaukanlah' dan 'tinggalkanlah' memiliki

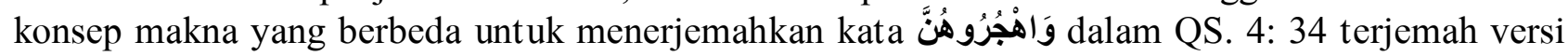
bahasa Malaysia dan bahasa Indonesia.

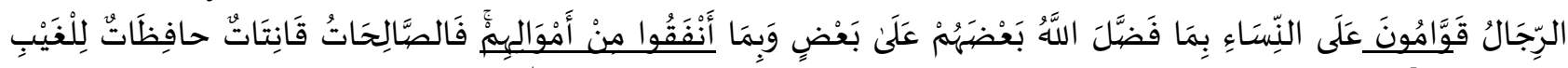

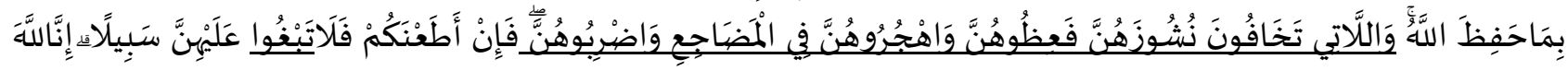




\section{Arabi : Journal of Arabic Studies}

Tabel 13. Terjemah QS. 4: 34 versi bahasa Malaysia dan bahasa Indonesia

Terjemah al-Qur'an Versi Bahasa Melayu

(Jakim)
Terjemah al-Qur'an Versi Bahasa Indonesia (Kemenag RI)
Kaum lelaki adalah pemimpin bagi wanita, kerana Allah telah melebihkan orang lelaki atas wanita, dan juga kerana orang lelaki telah membelanjakan dari harta mereka. Maka wanita yang salih itu ialah yang taat (kepada Allah dan suaminya), dan yang memelihara dirinya ketika suami tidak hadir bersama, dengan pemeliharaan Allah. Dan wanita-wanita yang kamu bimbang melakukan nusyuz hendaklah kamu menasihati mereka, dan pulaukanlah mereka di tempat tidur, dan pukullah mereka. Kemudian jika mereka taatkanmu, maka janganlah kamu mencari jalan untuk menyusahkan mereka.
Laki-laki (suami) itu pelindung bagi perempuan (istri), karena Allah telah melebihkan sebagian mereka (laki-laki) atas sebagian yang lain (perempuan), dan karena mereka (laki-laki) telah memberikan nafkah dari hartanya. Maka perempuan-perempuan yang saleh adalah mereka yang taat (kepada Allah) dan menjaga diri ketika (suaminya) tidak ada, karena Allah telah menjaga (mereka). Perempuan-perempuan yang kamu khawatirkan akan nusyuz, hendaklah kamu beri nasihat kepada mereka, tinggalkanlah mereka di tempat tidur (pisah ranjang), dan (kalau perlu) pukullah mereka. Tetapi jika mereka menaatimu, maka janganlah kamu mencari-cari alasan untuk menyusahkannya.

Pada terjemah versi Jakim, kalimat وَاهْجُرُوهُنَّ فِي الْمَضَنَجِع diterjemahkan dengan 'dan

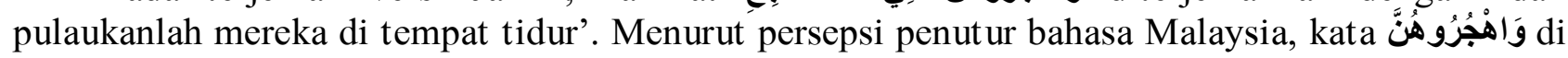
sini bisa digantikan: 'pulaukanlah; bisa digantikan dengan kata 'menjauhi, meninggalkan', namun tidak dapat digantikan dengan kata 'meracau', karena meracau berarti: cara bicara orang yang kemasukan setan. Pulaukanlah berarti: 'asingkan' atau 'pisahkan'. Maksud dari kata 'memulaukan' ialah meninggalkan dengan tidak ada komunikasi sebelum ia berubah. Dalam bahasa Malaysia, tidak menggunakan istilah pisah ranjang, tapi menggunakan istilah 'mengasingkan tempat tidur'. Adapun penggunaan kata 'pulaukanlah' sebagai berikut:

- pulaukanlah penjenayah itu (asingkan penjahat itu/ dipisahkan dari hidup bermasyarakat)

Menurut persepsi penutur bahasa Indonesia, kata 'tinggalkan' di sini ada yang menetap di tempat ada yang pergi (pisah ranjang) tetapi tetap menjalin komunikasi.

\section{Simpulan}

Berdasarkan data, konsep makna suatu kata dalam bahasa Malaysia cenderung dapat digunakan di berbagai konteks dan memiliki banyak makna (polisemi) jika dibandingkan dengan kata dalam bahasa Indonesia. Pada bahasa Malaysia dan Indonesia, terdapat konsep makna kata yang sama, baik makna kamus maupun makna terjemah al-Qur'an, meskipun terjadi perluasan makna penggunaannya, seperti kata 'hampir'. Faktor yang memengaruhi perbedaan konsep makna pada kedua kamus tersebut yaitu faktor sosial, budaya, politik, serta kebijakan pemerintah. AlQur'an terjemah versi bahasa Malaysia cenderung menggunakan ungkapan majazi, karena dipengaruhi budaya Melayu yang kaya akan ungkapan majazi dalam menyampaikan maksud dan tujuan sebagai cara untuk penghalusan makna. Al-Qur'an terjemah versi bahasa Malaysia menunjukkan makna yang lebih hati-hati dari larangan yang disebutkan di dalam ayat, sedangkan al-Qur'an terjemah Indonesia serasa lebih kontekstual dibandingkan terjemah versi Malaysia. Hal itu tidak lepas dari pengaruh pemikiran keislaman di Indonesia lebih moderat, toleran dan mengakomodir kearifan lokal. Berbeda dengan terjemah Malaysia serasa lebih tekstual dibandingkan terjemah versi Indonesia. Hal itu tidak terlepas corak pemikiran keislaman mereka yang formalistik dan tekstual.[] 


\section{Daftar Rujukan}

Abd. Rahman, Akmal Khuzairy. 2014. "Translating The Holy Koran Into The Malay Language: A General Overview On The History, Characteristics And Styles = Terjemahan Al-Quran Ke Dalam Bahasa Melayu: Pandangan Umum Terhadap Sejarah, Ciri-Ciri Dan Gaya Bahasa”, Journal Of Linguistic And Literary Studies, Vol. 5, No. 2.

Alfa, Muhammed Salisu., Hanafi Dollah., \& Nurazzelena Abdullah. 2015. “Analysis Of The Impact Of Arabic-Malay Bilingual Dictionaries In Malaysia”, Umran-International Journal Of Islamic And Civilizational Studies, Vol. 2, No. 3.

Astari, Rika., \& Betty Mauli Rosa Bustam. 2019. "A Semantic Analysis Of Difference Lexical Choices In Quran Translation Of Indonesian And Dutch Versions", Arabiyat: Jurnal Pendidikan Bahasa Arab Dan Kebahasaaraban, Vol. 6, No. 2.

Bin Khalid, Osman. 2016. Kamus Diwan: Arab-Melayu. Malaysia: DBP.

Bustam, Betty Mauli Rosa., \& Rika Astari. 2018. "Meaning Differences Between Two Quran Translation In Activism Era In Indonesia (Ideology In Translation Analysis)", Analisa: Journal of Social Science and Religion, Vol. 3, No. 1.

Haidar, Farid Awadh. 2005. 'Ilm al-Dalâlah: Dirasah Nazhariyyah Wa Tathbiqiyyah. Kairo: Maktabah Al-Adab.

Jabatan Kemajuan Islam Malaysia, “E-Qur'an: Terjemahan Al-Qur'an”, diakses dari http://www.islam.gov.my/e-jakim/e-quran/terjemahan-Al-Qur'an, pada 17 Maret 2017

Kamalie, Saifullah. 2011. “Al-Isykaliyyât Al-Lughawiyyah Fi Tarjamah Ma'ani Al-Qur'an AlKarim Ila Al-Lughah Al-Indonisiyyah”, Tsaqafah, Vol. 7, No. 1.

Kenny, Dorothy. 1998. "Creatures Of Habit? What Translators Usually Do With Words," Meta: Journal Des Traducteurs/Meta: Translators' Journal, Vol. 43, No. 4.

Komissarov, Vilen N. 1991. "Language And Culture In Translation: Competitors Or Collaborators?", TTR: Traduction, Terminologie, Redaction, Vol. 4, No. 1.

Komissarov, Vilen N. 1991. "Language And Culture In Translation: Competitors Or Collaborators?", Languages And Cultures In Translation Theories, Vol. 4, No. 1.

Mat, Azman Che. 2010. "Revisiting Arabic-Malay Translation Experience In Malaysia: A Historical And Contemporary Account”, Asian Culture And History, Vol. 2, No. 2.

Matsna, Moh. 2016. Kajian Semantik Arab. Jakarta: PT Fajar Interpratama Mandiri.

al-Mujahid, A. Thoha Husein., \& A. Atho'illah Fathoni Al-Khalil. 2016. Kamus al-Wafi ArabIndonesia. Jakarta: Gema Insani.

Nur, Tajudin. 2016. “Analisis Kontrastif Dalam Studi Bahasa”, Arabi: Journal of Arabic Studies, Vol. 1, No. 2.

Nur, Tajudin. 2018. "Pernyataan Kala Dan Aspek Dalam Bahasa Arab," Arabi: Journal of Arabic Studies, Vol. 3, No. 1.

Rohmana, Jajang A. 2014. "Memahami al-Qur'an Dengan Kearifan Lokal: Nuansa Budaya Sunda Dalam Tafsir Al-Qur' an Berbahasa Sunda”, Journal of Qur'an And Hadith Studies, Vol. 3, No. 1.

Shihab, M. Quraish. 2012. Tafsir Al-Misbah: Pesan, Kesan Dan Keserasian al-Qur'an. Jakarta: Lentera Hati.

Sudaryanto. 2015. Metode Dan Aneka Teknik Analisis Bahasa. Yogyakarta: APPTI. 
Arabi : Journal of Arabic Studies

Sundari, Hanna., \& Rina Husnaini Febriyanti. 2017. "Translation Techniques And Translation Competence In Translating Informative Text For Indonesian Efl Learners”, Scope: Journal of English Language Teaching, Vol. 1, No. 1.

Umar, Ahmad Mukhtar. 1998. Ilm Dilalah. Kairo: 'Alam Al-Kutub.

Wang, Caiwen. 2017. "Interpreters: Cultural Mediators", Translatologia: A Journal of Translation, Language and Literature, Vol. 1.

Wyszyńska, Joanna. 2017. "Ideology In Translation: Polish Literature Of World War Ii In Spanish Translations", Translatologia: A Journal of Translation, Language and Literature, Vol. 1.

Zaidan, Noor Azlina., Muhammad Azhar Zailaini, \& Wail Muin Ismail. 2015. "Absorption Of Arabic Words In Malay Language", Oida International Journal on Sustainable Development, Vol. 8, No. 6 . 